\title{
Differences in acetate recovery factor between groups may interfere with tracer estimates of fact oxidation.
}

Citation for published version (APA):

Borghouts, L., Schrauwen, P., Blaak, E. E., \& Wagenmakers, A. J. M. (2001). Differences in acetate recovery factor between groups may interfere with tracer estimates of fact oxidation. Journal of Applied Physiology, 90(6), 2520-2521. https://doi.org/10.1152/jappl.2001.90.6.2520

Document status and date:

Published: 01/01/2001

DOI:

10.1152/jappl.2001.90.6.2520

Document Version:

Publisher's PDF, also known as Version of record

\section{Document license:}

Taverne

\section{Please check the document version of this publication:}

- A submitted manuscript is the version of the article upon submission and before peer-review. There can be important differences between the submitted version and the official published version of record.

People interested in the research are advised to contact the author for the final version of the publication, or visit the DOI to the publisher's website.

- The final author version and the galley proof are versions of the publication after peer review.

- The final published version features the final layout of the paper including the volume, issue and page numbers.

Link to publication

\footnotetext{
General rights rights.

- You may freely distribute the URL identifying the publication in the public portal. please follow below link for the End User Agreement:

www.umlib.nl/taverne-license

Take down policy

If you believe that this document breaches copyright please contact us at:

repository@maastrichtuniversity.nl

providing details and we will investigate your claim.
}

Copyright and moral rights for the publications made accessible in the public portal are retained by the authors and/or other copyright owners and it is a condition of accessing publications that users recognise and abide by the legal requirements associated with these

- Users may download and print one copy of any publication from the public portal for the purpose of private study or research.

- You may not further distribute the material or use it for any profit-making activity or commercial gain

If the publication is distributed under the terms of Article $25 \mathrm{fa}$ of the Dutch Copyright Act, indicated by the "Taverne" license above,

Download date: 26 Apr. 2023 
The following is the abstract of the article discussed in the subsequent letter:

Horowitz, Jeffrey F, and Samuel Klein. Oxidation of nonplasma fatty acids during exercise is increased in women with abdominal obesity. J Appl Physiol 89: 2276-2282, 2000.-We evaluated plasma fatty acid availability and plasma and whole body fatty acid oxidation during exercise in five lean and five abdominally obese women (body mass index $=21 \pm 1$ vs. $38 \pm 1 \mathrm{~kg} / \mathrm{m}^{2}$ ), who were matched on aerobic fitness, to test the hypothesis that obesity alters the relative contribution of plasma and nonplasma fatty acids to total energy production during exercise. Subjects exercised on a recumbent cycle ergometer for $90 \mathrm{~min}$ at $54 \%$ of their peak oxygen consumption. Stable isotope tracer methods $\left(\left[{ }^{13} \mathrm{C}\right]\right.$ palmitate $)$ were used to measure fatty acid rate of appearance in plasma and the rate of plasma fatty acid oxidation, and indirect calorimetry was used to measure whole body substrate oxidation. During exercise, palmitate rate of appearance increased progressively and was similar in obese and lean groups between 60 and $90 \mathrm{~min}$ of exercise $[3.9 \pm 0.4$ vs. $4.0 \pm 0.3 \mu \mathrm{mol} \cdot \mathrm{kg}$ fat free mass $\left.(\mathrm{FFM})^{-1} \cdot \mathrm{min}^{-1}\right]$. The rate of plasma fatty acid oxidation was also similar in obese and lean subjects $(12.8 \pm 1.7$ vs. $14.5 \pm$ $1.8 \mu \mathrm{mol} \cdot \mathrm{kg} \mathrm{FFM}{ }^{-1} \cdot \min ^{-1} ; P=\operatorname{not}$ significant). However, whole body fatty acid oxidation during exercise was $25 \%$ greater in obese than in lean subjects $(21.9 \pm 1.2$ vs. $17.5 \pm$ $\left.1.6 \mu \mathrm{mol} \cdot \mathrm{kg} \mathrm{FFM}{ }^{-1} \cdot \mathrm{min}^{-1} ; P<0.05\right)$. These results demonstrate that, although plasma fatty acid availability and oxidation are similar during exercise in lean and obese women, women with abdominal obesity use more fat as a fuel by oxidizing more nonplasma fatty acids.

\section{Differences in Acetate Recovery Factor Between Groups May Interfere With Tracer Estimates of Fat Oxidation}

To the Editor: Stable isotope tracer methodology can be used to make estimates of the oxidation rates of plasma fatty acids (FAs) and nonplasma FAs during exercise (2-4). Plasma FAs are liberated from adipose tissue, whereas nonplasma FAs are liberated in the muscle via hydrolysis of intramuscular triglycerides or in the muscle capillary bed after hydrolysis of very low-density lipoprotein-triglycerides. In their recent paper (1), Horowitz and Klein have used these methods and conclude that women with abdominal obesity have an increased oxidation rate of nonplasma FAs during exercise. To correct tracer estimates of FA oxidation for tracer loss in exchange reactions of the tricarboxylic acid cycle, it is imperative to use an acetate recovery factor (ARF) (4). Horowitz and Klein (1) used an assumed value of 0.80 for the ARF in both groups. This value was based on a relationship between ARF and oxygen consumption (in $\mathrm{ml} \cdot \mathrm{kg}^{-1} \cdot \mathrm{min}^{-1}$ ) during exercise that was published by Sidossis et al. (4) for a group of young lean subjects. However, when we convert the oxygen consumption values for the groups studied by Horowitz and Klein (1) to milliliters per kilogram per minute and then apply the relationship reported by Sidossis et al. (4) to calculate the ARF, then we find a lower value for the obese subjects (0.71) than for the controls (0.80). This leads to an overestimation of nonplasma FA oxidation in the obese subjects in the study of Horowitz and Klein (1). Furthermore, we have shown that, although the ARF is reproducible within a subject, it has a high interindividual variability (3). Recently, we also showed that the ARF differs significantly between lean, obese, and Type 2 diabetic subjects (2). This variability was partly accounted for by percent body fat. Therefore, application of the same $\mathrm{ARF}$ in obese and lean subjects could result in a miscalculation of the oxidation of the various fat sources and their relative contribution. To illustrate this, we have used the relationship that we reported between percent body fat and ARF during exercise (2) to recalculate the values reported by Horowitz and Klein (1). The differences in relative contribution of plasma FAs and nonplasma FAs to total fat oxidation becomes minimal in that case (92 and $8 \%$ in lean and 88 and $12 \%$ in obese subjects, respectively). Horowitz and Klein reported respective values of 83 and $17 \%$ in lean and 58 and $42 \%$ in obese subjects.

It should be noted that we do not claim that Horowitz and Klein (1) should have used the ARFs that we published (2). This is primarily because we used [1,2$\left.{ }^{13} \mathrm{C}\right]$ acetate $(2,3)$, whereas $\left[1-{ }^{13} \mathrm{C}\right]$ acetate was used in the studies of Horowitz and Klein (1) and Sidossis et al. (4). The use of $\left[1-{ }^{13} \mathrm{C}\right]$ acetate in group comparisons would cause a slight difference in the absolute ARF values. However, the relative difference between the groups would most likely be similar to our results (2). Therefore, we believe the recalculations do illustrate that failure to account for differences in ARF between groups may have resulted in an artificial increase in the estimated ability of obese women to oxidize nonplasma FAs. More in general, it shows that the assumption of a single value for the ARF in different individuals and groups may have pronounced effects on the outcome of tracer studies and could potentially lead to erroneous conclusions. Because of the high interindividual variability in $\mathrm{ARF}$, we recommend that the ARF is determined in each and every subject $(2,3)$.

\section{REFERENCES}

1. Horowitz JF and Klein S. Oxidation of nonplasma fatty acids during exercise is increased in women with abdominal obesity. J Appl Physiol 89: 2276-2282, 2000.

2. Schrauwen $P$, Blaak EE, Van Aggel-Leijssen DP, Borghouts LB, and Wagenmakers AJ. Determinants of the acetate recov- 
ery factor: implications for estimation of $\left[{ }^{13} \mathrm{C}\right]$ substrate oxidation. Clin Sci (Colch) 98: 587-592, 2000.

3. Schrauwen P, van Aggel Leijssen DP, van Marken Lichtenbelt WD, van Baak MA, Gijsen AP, and Wagenmakers AJ. Validation of the $\left[1,2-^{13} \mathrm{C}\right]$ acetate recovery factor for correction of [U-13 C]palmitate oxidation rates in humans. $J$ Physiol (Lond) 513: 215-223, 1998.

4. Sidossis LS, Coggan AR, Gastaldelli A, and Wolfe RR. A new correction factor for use in tracer estimations of plasma fatty acid oxidation. Am J Physiol Endocrinol Metab 269: E649-E656, 1995.

Lars B. Borghouts

Department of Movement Sciences

Maastricht University

6200 MD Maastricht, The Netherlands

Patrick Schrauwen

Ellen E. Blaak

Anton J. M. Wagenmakers

Department of Human Biology

Maastricht University

6200 MD Maastricht, The Netherlands

\section{REPLY}

To the Editor: Bourghouts and colleagues raise several important issues regarding the analysis of plasma fatty acid oxidation during exercise. The intravenous infusion of a carbon-labeled fatty acid in conjunction with measuring the appearance of labeled carbon dioxide in breath is typically used to evaluate the oxidation rate of plasma fatty acids. However, this approach is imperfect because some of the $\left[{ }^{13} \mathrm{C}\right]$ (or $\left[{ }^{14} \mathrm{C}\right]$ ) label becomes fixed within nonoxidative metabolic pathways and is not available for release into expired air.

The latest method used to correct for the fixation of infused label is to assess the recovery of label in expired carbon dioxide from infused $\left[{ }^{13} \mathrm{C}\right]$ acetate $(4)$. In our study (2), we did not use an assumed ARF for all subjects but calculated an ARF for each subject by using the equation reported by Sidossis et al. (4), which we adjusted for fat-free mass (FFM). The mean acetate correction factors calculated for our lean and obese women were $0.80 \pm 0.01$ and $0.80 \pm 0.02$, respectively. Failing to adjust for FFM and using a mean ARF for all subjects, as Bourghouts and colleagues did in reevaluating our data, can lead to significant errors in estimating plasma fatty acid oxidation.

In a recent study (which appeared in print after our article was accepted for publication), Borghouts and colleagues found that the ARF during exercise varied with percent body fat in their male subjects (3). This observation led to their concern that the similar ARF values in our lean and obese subjects may have been incorrect and could have resulted in erroneous estimates of plasma fatty acid oxidation rates. However, other data from their study (3) demonstrated that the ARF during exercise was highly correlated with energy expenditure adjusted for FFM in all subjects. Therefore, their data indicate that ARF was similar in lean and obese subjects exercising at the same energy expenditure relative to FFM (3). This makes sense because it is assumed that most of the tracer loss occurs in the exercising musculature. In our study, we pur- posely matched our lean and obese subjects for peak oxygen consumption relative to FFM, so energy expenditure adjusted for FFM during exercise was identical in both groups. Therefore, the ARF should have also been similar in our lean and obese subjects.

Additional data from our study (2) and data from another report (1) support our conclusion that the oxidation of nonplasma fatty acids during exercise was greater in our obese than in our lean subjects. We found that total fat oxidation during exercise, measured by open-circuit spirometry, was $25 \%$ greater in our obese than in our lean women. However, tissue uptake of plasma fatty acids, measured by standard isotope dilution methods, was the same in both groups. Therefore, these data indicate that the additional fatty acids that were oxidized by our obese subjects originated from nonplasma fatty acids. Moreover, our findings are consistent with a recent study, reported in abstract form by Goodpaster et al. (1), that found that the oxidation of nonplasma fatty acids during exercise was greater in obese than in lean men.

We agree with Bourghouts and colleagues that the best approach for evaluating plasma fatty acid oxidation rates during exercise is to directly measure the $\mathrm{ARF}$ in each study subject. However, absence of this direct measurement should not preclude the assessment of plasma fatty acid oxidation if precautions are taken to control for factors that affect ARF. Nonetheless, it should be noted that the direct measurement of ARF is based on the unproven assumption that acetate and fatty acids are metabolized in the same proportion in the same tissues or that all tissues generate the same relative amount of label fixation. For example, greater metabolism of acetate in liver than in skeletal muscle during exercise would generate an ARF based primarily on hepatic, not muscle, acetate metabolism. Therefore, measuring the ARF may not completely eliminate possible errors in assessing plasma fatty acid oxidation rate.

\section{REFERENCES}

1. Goodpaster BH, Jakicic JM, Winters C, and Kelley DE. Effects of obesity on substrate utilization during exercise (Abstract). Med Sci Sports Exerc 31, Suppl 5: S340, 2000.

2. Horowitz JF and Klein S. Oxidation of nonplasma fatty acids during exercise is increased in women with abdominal obesity. J Appl Physiol 89: 2276-2282, 2000.

3. Schrauwen P, Blaak EE, Van Aggel-Leijssen DP, Borghouts LB, and Wagenmakers AJM. Determinants of the acetate recovery factor: implications for estimation of $\left[{ }^{13} \mathrm{C}\right]$ substrate oxidation. Clin Sci (Colch) 98: 587-592, 2000.

4. Sidossis LS, Coggan AR, Gastaldelli A, and Wolfe RR. A new correction factor for use in tracer estimations of plasma fatty acid oxidation. Am J Physiol Endocrinol Metab 269: E649-E656, 1995.

Jeffrey F. Horowitz

Division of Kinesiology

University of Michigan

Ann Arbor, Michigan 48109

Samuel Klein

Department of Internal Medicine

Washington University School of Medicine

St. Louis, Missouri 63110 